\title{
AREAS APLICATIONS AND LEARNING FUNCTIONS IN WEBCASTING SYSTEMS
}

\section{Milan NOVÁK}

\begin{abstract}
The article interoduces possibilities application of webcasting systems in scope of extensive tutorial background. Emphasis is above on current data trends in form individuation of teaching there by also search in a new pedagogic methods. The one of possibility is an aplication of new technology what are e.g.webcastings systems.
\end{abstract}

Key words: webcasting, education, learning function, video, learning object, educational system

\section{OBLASTI APLIKACE A VÝUKOVÉ FUNKCE WEBCASTINGOVÝCH SYSTÉMŮ}

Resumé: Článek předkládá možnosti aplikace webcastingových systémů v rámci rozsáhlého výukového prostředí. Dưraz je především kladen na současné trendy v podobě individualizace učení a tím i hledání nových pedagogických metod. Jednou z možností je využití nových technologii jakými jsou napr. webcastingové systémy.

Kličová slova: webcasting, vzdělávání, výukové funkce, video, výukový objekt, vzdělávací systém

\section{1 Úvod}

Základními podněty pro využivání webcastingových systémů jsou proměny, kterými prochází vzdělávání, které vyvolávají procesy globalizace, znalostní ekonomiky a celoživotního učení. Mnoho změn lze vnímat jako podněty $\mathrm{k}$ diskusi o samé podstatě vyučovacího procesu a současně jako otázky, na které je zapotřebí odpovědět změnou $\mathrm{v}$ chápání tradičních pohledů na smysl a postavení webcastingových systémů $\mathrm{v}$ procesech učení. Dochází $\mathrm{k}$ vzájemnému posunu od jednoho parametru k druhému (1, s. 25). Tyto změny lze vyjádřit jako přechod od vyučování a výcviku k učení, od učení se jako procesu k učení se jako institucionálnímu fenoménu ve smyslu učících se organizací, od mechanického, bezmyšlenkovité učení k reflektivnímu učení odrážejícímu reálný život a praxi, od učení tváří $\mathrm{v}$ tvář $\mathrm{k}$ učení distančnímu, resp. k e-learningu.

\section{Trendy v tvorbě výukových materiálů}

Uvedené podněty lze shrnout do několika trendů a požadavků na tvorbu výukových materiálů a jejich využívání prostřednictvím webcastingových systémů.

- Webcastingové systémy a $\mathrm{v}$ obecné rovině média se budou stále více využívat jako nástroj celoživotního učení v konkrétních podmínkách organizací.

- Webcastingové systémy musí přinášet pohotové a aktuální informace a umožňovat náhledy do reálných problémů a situací.
- Webcastingové systémy se musí více orientovat na využití jako nástroje učícího se jedince. To vyžaduje jejich uživatelskou prrívětivost (snadnou ovladatelnost), větší míru interpretačních informací, tj. informací, které budou řídit (motivovat, regulovat a hodnotit proces) samostatného učení jedince. Budou spíše než ve škole sloužit učícím se jedincưm doma, eventuálně v zaměstnání.

- Webcastingové systémy budou přispívat $\mathrm{k}$ interdisciplinárnímu pohledu na studovanou realitu.

Výše uvedený trend zvyšování podílu individuálního učení, poukazuje na požadavek hledání nových pedagogických př́stupů s využitím moderních technologií, jakými jsou např́íklad právě webcastingové systémy. Pro poukázání na oblasti využitelnosti webcastingových systémů, které vychází z předchozích odstavců, je patrné, že jejich vymezení lze uskutečnit $\mathrm{z}$ několika hledisek. Prvním z nich je na základě vymezení forem vzdělávání - tedy prezenčního a distančního vzdělávání.

\section{Webcastingové systémy a formy výuky}

V pojetí prezenční výuky, která má své charakteristické rysy se využití webcastingových systémů omezuje na podporu klasické výuky, která se $\mathrm{v}$ anglické terminologii nazývá také jako face to face learning (resp. F2F learning). 
Základní a střední školy jsou z důvodů široké škály funkcí (2, s. 20-25) orientovány na prezenční výuku. Nicméně poznatky o stylech učení, specifických vývojových poruchách učení, problémech integrace handicapovaných jedinců do běžných studentských kolektivů, záměr rozvíjet talenty budou prrispívat $\mathrm{k}$ větší diferenciaci vyučování a $\mathrm{k}$ hledání individuální, více individualizované cesty pro dosažení didaktických cílů.

Z hlediska uplatnění webcastingových systémů $\mathrm{v}$ prezenční formě vyučování bude dominovat využití takových výukových postupů, které spíše koncentrují jejich využití do rukou učitele pro prezentování učební informací. Převahu bude mít spíše motivační a informačně expoziční funkce webcastingových systémů. Přes značný pokrok ve vybavování škol prostředky informačních a komunikačních technologií nelze reálně očekávat, že by každý student měl ve škole $k$ nepřetržitému osobnímu použití vlastní počítač $\mathrm{V}$ kterékoliv jeho cenové, technické nebo výkonnostní variantě. Budované studovny (nebo studijně informační centra) na většině škol vybavené počítači však mohou zvyšovat podíl řízené samostatné práce studentů prostřednictvím webcastingových systémů bez ohledu na to, zda jde o samostatnou práci $\mathrm{v}$ průběhu nařízeného počtu vyučovacích hodin nebo v době osobního volna studentů.

Podle výše uvedených významných změn ve vzdělávání, lze webcastingové systémy v podobě slovně názorné metody předurčit pro transfer informací směrem od učitele k studentům. Dále studentům umožňují samostatné vyhledáváním informací pomocí interaktivních nástrojů, věnovat se diskusím, řešení modelových situací, týmovému řešení projektů apod.

Webcastingové systémy na základních a středních školách $\mathrm{v}$ prezenční formě studia budou především zajišt'ovat prezentaci asynchronních audiovizuálních záznamů typu instrukce a mohou být využity jako doplněk klasické vyučovací hodiny. $\mathrm{Na}$ úrovni samostatného studia studentů lze prezentovat celé výukové události $\mathrm{v}$ podobě záznamu výukové hodiny, s možností interaktivní zpětné vazby. Webcastingové systémy v prezenční formě studia na vysokých školách mají uplatnění jak v synchronních, tak i asynchronních výukových událostech. Plně substituují klasické přednášky s možností jejich archivace pro další využívání na žádost.
Webcastingové systémy mohou být aplikovány do široké škály školních předmětů a oblastí vzdělávání zejména na středních a vysokých školách, ale též a především v postgraduálním odborném vzdělávání $\mathrm{v}$ různých manažerských a rekvalifikačních kurzech. Lze uplatňovat další metody vzdělávání, a to především kombinované a distanční, které se vyskytují v převážné míre na vysokých školách. Ukazuje se, že pole působnosti a využití metod kombinovaného i distančního vzdělávání je neobyčejně široké a rozmanité, přizpůsobující možnostem, zájmům a zaměření vzdělávaných.

Vhodnost webcastingových systémů pro distanční vzdělávání vyplývá z jeho samotného popisu, který uvádí, že je do jisté míry opakem prezenčního studia. Je to studium samostatné, podporované speciálně zpracovanými studijními pomůckami (oporami). Distanční studium v maximální možné míre využívá pro vzdělávací proces multimediálních prostředků a informačních technologií. Studující jsou převážně nebo zcela fyzicky odděleni od vzdělávací instituce, která jejich studium řídí a podporuje (3). Tyto uvedené požadavky distančního vzdělávání mohou být splněny interaktivními nástroji webcastingových systémů.

Perspektivní oblastí vzdělávání současné doby je použití blended learningu v kurzech vysokoškolského, rekvalifikačního i celoživotního studia, jak pro pregraduální prípravu, tak i pro distanční a online kurzy. Blended learning kombinuje rozmanité způsoby přenosu informací mezi učitelem a studentem (4). Pojmu blended learning ve smyslu „smíšené, mixované či kombinované vzdělávání" se také často užívá k popisu vzdělávání, které kombinuje řadu aktivit, jako př́má výuka „tváŕí $\mathrm{v}$ tváŕc v rámci tř́́d, „živý e-learning“ a individuální vzdělávání vlastní rychlostí - samostudium (selfpaced learning). Cílem je dát každému studujícímu $\mathrm{k}$ dispozici pro každou výukovou činnost takové prostředí, $\mathrm{v}$ němž je schopen pracovat co nejefektivněji. Proto se nejčastěji kombinuje osobní kontakt učitele a studentů s e-learningem, tj. všemožným zapojením technologií (komunikace, synchronní i asynchronní spolupráce, využití systémů kontroly a řízení výuky, samostatné studium $\mathrm{s}$ podporou elektronických materiálů apod.). Blended learning tak umožňuje realizaci vysoce efektivního studia.

Dnes je možné považovat za prokázané, že kombinované formy vzdělávání jsou vzhledem 
k širším možnostem, které poskytují, výhodnější než metody tradiční. Jsou však zároveň též úspěšnější než metody čistě e-learnigové (distanční), kterým byla ještě před několika lety přisuzována velká budoucnost. Blended learning $\mathrm{v}$ sobě zahrnuje celou řadu metod, kterými lze účinně působit na vzdělávací proces a které uživateli - vzdělávanému prezentují vzdělávací obsahy prostřednictvím vhodného softwaru. $Z$ tohoto důvodu lze velmi efektivně využívat webcastingové systémy i v této výukové formě.

\section{Vymezení funkcí webcastingových systémů}

$\mathrm{S}$ uvedenými možnostmi aplikovatelnosti webcastingových systémů do různých oblastí vzdělávání vyvstává otázka, zda distanční či kombinované vzdělávání může plnit a zastat rozmanité funkce kladené na různé stupně škol. Druhou otázkou je, zda webcastingové systémy klasifikované jako didaktický prostředek a aplikované pro uvedené formy vzdělávání, budou splňovat požadované funkce samotného vzdělávacího procesu.

Tyto funkce jsou vymezeny jednak z pohledu př́slušných etap vyučovacího procesu a dále jako funkce technických výukových prostředků. $\mathrm{Z}$ pohledu vyučovacího procesu to jsou zejména funkce:

Informativní funkce - zprostředkovává informace studentům prostřednictvím prezentace poznatků, znázorňování, rozvojem představ, vytvářením pojmů.

Formativní funkce - formuje osobnost studenta rozvojem aktivity, samostatností, tvořivostí.

Instrumentální funkce - osvojené vědomosti a dovednosti se stávají nástroji (instrumenty), dalších učebních činností.

Integrující funkce - organicky spojuje všechny uvedené funkce $(5$, s. 43$)$.

Každá $\mathrm{z}$ těchto funkcí má své těžiště $\mathrm{v}$ prŕíslušné etapě, i když ve vzájemné jednotě $\mathrm{s}$ dalšími funkcemi určují průběh celého vyučování. Vymezení jednotlivých funkcí v souvislosti s etapami vyučovacího procesu má význam pro plánování výchovně vzdělávací práce a pro volbu vyučovacích metod při poskytování výukových materiálů prostřednictvím webcastingových systémů.

Komplexní webcastingové systémy disponují specifickými technickými výukovými prostředky a v této souvislosti se vymezují jejich základní funkce, které se definují v „základní vrstvě“ $\mathrm{a}$, ,vrstvě obecnější“ $(6$, s.105). Mezi dílčí funkce technických výukových prostředků jsou řazeny funkce:

Motivačně stimulačni - zajištujue působení emociálně motivační. Dochází zejména k navození kladného vztahu k učení, zvýšení aktivity, stimulace zájmu, potlačení rušivých podnětů. Ve webcastingových systémech se uplatňuje vhodným působením na emocionálně motivační sféru studentovy osobnosti. Zejména se jedná o motivaci obsahovou, formou sdělování informací, které si kladou za cíl motivovat studenty $\mathrm{k}$ úvaze o učivu, aktivizovat je a vzbudit jejich zájem a záměrnou pozornost a celkově navodit kladný vztah k učení.

Specifickým prvkem webcastingových systémů s ohledem na motivační činitele je možnost prezentace výukových informací jako živou událost nebo formou na vyžádání, tj. ze záznamu. Při živé události je hlavním motivačním činitelem samotný vyučující, který prezentuje výukový obsah nebo se jedná o výrazové prostředky audiovizuálního záznamu. $\mathrm{V}$ obou možnostech jsou $\mathrm{k}$ dispozici interaktivní komunikační nástroje zajišt'ující důležité motivační hledisko, kterým je zpětná vazba.

Informačně expozični - v jejím základním pojetí přináší využití zejména při získávání a prezentaci informací s důrazem na možnosti současných technických výukových prostředků, multikanálové působení, zvýšení názornosti výuky. Webcastingové systému ve vztahu $\mathrm{k}$ této funkci se stávají zdrojem jasných představ a vnější oporou myšlenkových činností.

Existuje několik základních jevů a dějů, při jejichž znázorňování se webcastingové systémy využívají nejčastěji. Jedná se především o znázorňování skutečností časově nebo prostorově vzdálených, těžko př́stupných nebo nebezpečných, lidskému vnímání nedostupných, jinak vůbec neznázornitelných nebo objektivně neexistujících

Repetičně fixační - působí při osvojování prezentovaného učiva, jeho fixaci a retenci. Tato funkce mimo jiné poukazuje na to, jak student pracuje nejprve na základě rozličných cvičení $\mathrm{s}$ tou částí učiva, která byla vyložena a poté si je procvičuje a upevňuje na nových př́kladech a v nových souvislostech, napomáhajících hlubšímu postižení vztahů, proniknutí $\mathrm{k}$ podstatě, $\mathrm{k}$ pochopení učiva i $\mathrm{k}$ upevnění a rozvoji získaných vědomostí a dovedností. $\mathrm{V}$ rámci webcastingových systémů tato funkce zohledňuje zejména metody organizace práce 
s exponovaným materiálem, respektive fixačních procesů.

Aplikačni - zajištuje využívání získaných informací ve formě poznatků, vědomostí a dovedností, transfer učiva do praxe, při ověřvání získaných poznatků $\mathrm{v}$ praxi a jejich zařazování do širších souvislostí. V této funkci se webcastingové systémy mohou uplatňovat především ve fázi aplikace na vyústění poznávacího procesu, tj. při používání získaných vědomostí a dovedností při spojování teoretických vědomostí a jejich využívání při transferu učiva do praxe, při ověrování získaných poznatků $\mathrm{v}$ praxi a při jejich zařazování do širších souvislostí (6, s. 32).

Kontrolně diagnostická - je obsažena ve všech fázích vyučovacího procesu, zahrnuje vstup, průběh a výsledky, vyučovací proces jako uzavřený zpětnovazební systém, členění vazeb, důraz na objektivizaci a racionalizaci diagnostiky a kontroly. Diagnostika, resp. kontrola a autokontrola má zásadní význam jak pro učitele, tak i pro samotného studenta. Je tedy zdrojem diagnostických informací, které jsou důležitou součástí pro úspěšné plánování, řízení a regulaci vyučovacího procesu.

Uvedené funkce jsou doplňovány o další, obecnějšího charakteru, které všechny dílčí funkce v sobě zahrnují:

Ř́díci - se podílejí na řízení vyučovacího procesu jako celku prostřednictvím nástrojů bezprostředního ř́zení, regulace a kontroly učebních činností studentů.

Komunikační - zajištuje odevzdávání, přenášení a prijímání různých informačních obsahů mezi učitelem (webcastingovým systémem) a studentem, tj. ve vzájemné výměně informací za využití různých forem interaktivních prostředků komunikace.

Celý systém funkcí zastřešuje funkce racionalizační, která zaujímá do značné míry specifické postavení. Racionalizační funkce postihuje racionalizační stránku každé dílčí nebo obecné funkce a zahrnuje tak $\mathrm{v}$ sobě veškeré racionalizační aspekty plynoucí z aplikace webcastingových systémů (7, s. 56).

\section{Závěr}

Uvedená analýza zabývající se poskytnutím informací o možnostech využití webcastingových systémů s hlediska různých forem výuky, spolu s odůvodněním možných aplikací s přihlédnutím na uvedené výukové funkce, umožňuje sestavit přesnější model webcastingového systému tak, aby poskytoval konkrétnější implementovatelnost. Tento aspekt se odrazí zejména $\mathrm{v}$ následné detailnější, resp. cílenější prípravě výukových mikroobjektů prostřednictvím webcastingových systémů.

\section{Literatura}

[1] JARVIS, P., HOLFORD, J., GRIFFIN,C. The theory and practise of learning. London : Kogan Page, 2003. ISBN 0-7494-3859-2.

[2] MALACH, J. Školní pedagogika. Ostrava : Pedagogická fakulta Ostravské univerzity, 2002. ISBN 80-7042-255-6.

[3] ZLÁMALOVÁ, H. Principy distanční vzdělávaci technologie a možnosti jejího využití v pedagogické praxi na technických vysokých školách. Centrum distančního vzdělávání. 2002. Dostupný $\quad \mathrm{z}$ WWW: $<$ http://icosym.cvut.cz/telel/zlamalova.html $>$.

[4] KOPECKÝ, K. Modely tzv.blended learningu (úvod do problematiky) [online]. Net-University s.r.o. Olomouc: Net-University, 2004. Dostupné z: <http://www.net-university.cz/blended.php >

[5] NELEŠOVSKÁ, A.,SPÁČILOVÁ, H. Didaktika II. Olomouc: Vydavatelství Univerzity Palackého, 1995.

[6] RAMBOUSEK, V. Technické výukové prostředky. 1. vyd. Praha: SPN, 1989. ISBN 14703-89.

[7] 212 RAMBOUSEK, V. Funkce technických výukových prostředků ve vyučovacím procesu na základní a střední škole. In FIALOVÁ, I. Didaktická technologie : sbornik védeckovýzkumných a metodických prací. 1. vyd. Univerzita Karlova : Karolinum, 1994. s. 56. ISBN 80-7066-851-2. [8] MÜHLBACHER, H. Selektivni propagace. [s.1.] : Babtex, 1993. $288 \mathrm{~s}$. ISBN 80-901444-6-2.

PhDr. Milan Novák, Ph.D.

Katedra informatiky

Pedagogická fakulta Jihočeské univerzity

Jeronýmova 1

37001 , České Budějovice, ČR

Tel: +420 7773081

E-mail: novis@pf.jcu.cz

Www pracoviště: http://wvc.pf.jcu.cz/ki/ 